\title{
Tectonic Evolution of the High Pressure Granulites in THE TETONS; THE EARLIEST RECORD FOR HimAlayAN-STYLE TECTONICS IN THE WORLD
}

\author{
B. RONALD FROST - DEPARTMENT OF GEOLOGY AND GEOPHYSICS \\ UNIVERSITY OF WYOMING — LARAMIE
}

Our field season in August 2005 consisted of mapping an area from Hidden Corral in the S. Fork Bitch Creek (which is not in the Grand Teton National Park) to Moose Basin. In addition to mapping and sampling in Moose Basin area we made an important traverse along the head of the cirque around Camp Lake (which lies just west of the Park).

As the result of our fieldwork in 2004 and 2005 we now recognize four distinct units in the basement gneiss of the Northern Teton Range (Fig. 1). One unit, which we call the Moose Basin gneiss, consists of intensely interfolded pelitic and mafic gneisses that locally retain evidence of high-pressure, high-temperature metamorphism. The Moose Basin gneiss lies upon the leucogranitic Webb Canyon gneiss, which lacks any sign of this high-pressure metamorphism. The other two units in the northern Teton Range are the layered gneiss and the augen gneiss. Both of these are quartzo-feldspathic gneisses. The augen gneiss is distinctive in that it clearly retains evidence of an igneous parent. Such evidence is cryptic in the layered gneiss. Neither unit shows evidence for the high-P metamorphism seen in the Moose Basin gneiss.

During our 2005 fieldwork we collected petrologic samples of the Moose Basin gneiss in upper Moose basin and measured structural features in the Moose Basin gneiss in a traverse from Moose Basin to west of Camp Lake. This involved measuring the orientation of planar features, linear features, and small-scale folds within the gneiss. We discovered that the Moose Basin gneiss occupies in a broad synform, the axis of which lies less than a kilometer west of Camp Lake (Fig 1). The Webb Canyon

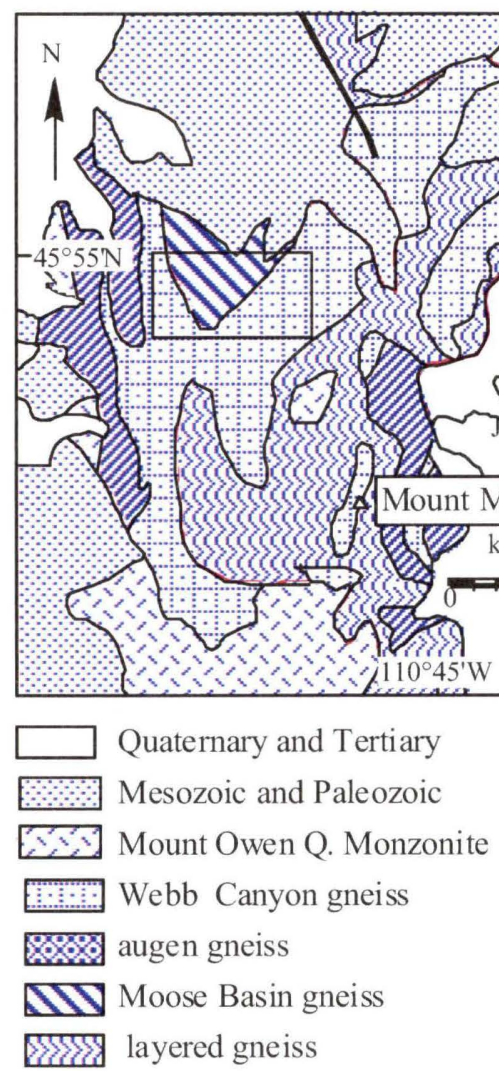

Figure 1. Geologic map of the Northern Teton range revised after Reed (1973). Small box shows the approximate location of the block diagram in Figure 2. 


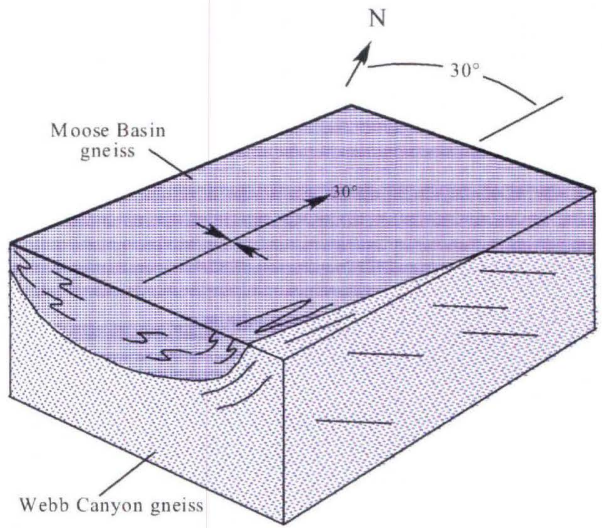

Figure 2. Block diagram showing the relation between the Moose Basin gneiss and the Webb Canyon gneiss.

gneiss abuts the Moose Basin gneiss on both the east (along the upper stretches of Webb Creek) and the west (on the west side of South Bitch Creek) of this fold. In both areas the Webb Canyon gneiss dips beneath the Moose Basin gneiss (Fig. 2). These relations suggest that the Webb Canyon gneiss lies beneath the Moose Basin gneiss and separates it from the layered gneiss and augen gneiss.

\section{Petrology}

Our petrologic observations indicate that the peak metamorphism in the Moose Basin gneiss occurred at $\mathrm{T}>900^{\circ} \mathrm{C}$ and $\mathrm{P} \sim 12$ kilobars (Figure 3 ). Very little is left of these peak mineral assemblages because the rock underwent extensive deformation and re-equilibration during uplift. Relict features we have found include evidence of partial melting in the mafic rocks that produced garnet, high $\mathrm{Zr}$ rutile in the pelitic rocks as well as sillimanite needles in garnet. The major deformations affecting the Moose basin gneiss took place as the rock cooled and decompressed from these peak conditions. Fluids were able to gain access to the rock during these deformation events, causing hornblende to form from the pyroxenes in the mafic rocks and biotite and kyanite to grow in the pelitic rocks. The presence of late staurolite, sillimanite, and cordierite indicate that the pelitic rocks underwent considerable decompression on cooling (dashed arrow on Figure $3)$.

\section{Implications and Further work}

The structural relations discovered in the summer of 2005 lend credence to our theory that the high-pressure Moose Basin gneiss was thrust onto the rest of the gneisses in the Tetons 2.67 billion years ago and that the Webb Canyon gneiss later intruded the thrust fault. High-pressure metamorphism such as recorded in the Tetons is rare in rocks older than
2.5 billion years old and is found today only in continent-continent collisions such as the Himalaya. This means that the gneisses in the Tetons record one of the oldest Himalayan-type mountain building events on Earth.

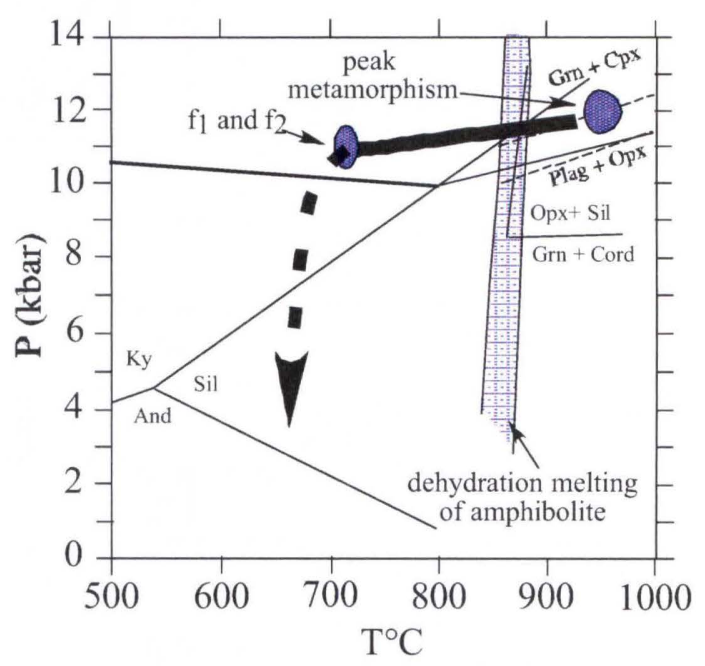

Figure 3. Inferred P-T path for the Moose Basin gneiss.

In December of 2005 we learned that NSF was going to provide us with $\$ 216,000$ to continue our study of the basement granulites in the Tetons. Studies we intend to pursue with this grant include:

1) We will determine the structural relations between the Webb canyon gneiss and the underlying layered gneiss. In particular we wish to learn whether these rocks record evidence of the tectonic emplacement of the Moose Basin gneiss

2) We hope to determine the structural, metamorphism, and plutonic history of the layered gneiss. The layered gneiss is the rock upon which the Moose Basin gneiss was thrust. We wish to find if there is a "basement" to this complex or whether it consists of an accretionary prism. If so it would have formed as an agglomeration of rocks that at ca. 2.68 billion years ago, lay ocean-ward of an island arc.

3) We intend to undertake the detailed geochronological studies of the rocks in the Tetons to determine the age of the various structural and metamorphic events within the Moose Basin gneiss, Webb Canyon gneiss, and the layered gneiss.

\section{$\downarrow$ Literature Cited}

Reed, J.C., Jr. 1973. Geologic map of the Teton Range, Wyoming. United States Geological Survey, Open-File Map 73-230 Scale 1: 62600 